\title{
The revelation of Christ as an impossible impossibility: a critical reading of Jean-Luc Marion's contribution to the post-modern debate in phenomenology, philosophy of religion and theology
}

\author{
Compaan, Auke \\ University of Pretoria \\ auke@skuilkrans.co.za
}

\begin{abstract}
This article is an attempt to establish the phenomenological and theological value of the concept of Revelation in the work of the French philosopher Jean-Luc Marion in a post-modern cultural and intellectual context. Is it possible to speak of revelation in a phenomenological sense and more radically, about the Revelation of God, after the critique of metaphysics and phenomenology by Derrida, Caputo and others? Marion argues that by overcoming metaphysics and broadening the limits of traditional phenomenology to include phenomena of Revelation, the Revelation of Christ is a phenomenological impossible impossibility. Using Marion's reinterpretation of Husserl and Heidegger's understanding of "givenness", "the given" and the "gift" and his concept of Revelation as a saturated phenomenon, I want to critically illuminate his contribution to the concept of Revelation as a post-metaphysical and theological possibility.
\end{abstract}

Keywords

Revelation, Metaphysics, Phenomenology, Givenness, Impossibility

\section{Jean-Luc Marion and the theological turn in phenomenology}

The F rench p hilosopher J ean-Luc M arion is t oday w idely c onsidered to be among the foremost philosophers of his generation. What makes him inviting for theology, is that as a scholar in the phenomenological tradition of Husserl, Heidegger, Levinas and Derrida, he mediates and reflects upon the concept of Revelation as a phenomenological and theological possibility. For Marion the Revelation of God can be considered a possible 
phenomenon. This represents a radical turn in phenomenology, because the "phenomenological reduction" of Husserl, in his attempt to give knowledge of reality a sure epistemological foothold, was interpreted in the $20^{\text {th }}$ century in such a way that the question of God, or the transcendence of God, had to be put between brackets. The possibility of the Revelation of God was apparently the last thing that occupied $20^{\text {th }}$ century phenomenology. This has changed completely the last thirty years. The last decades there were even talked of a "theological turn" in phenomenology. What is novel in phenomenology is that it answers questions about God, not from any pregiven dogmatic concept of God, but beginning with experience. It uses the work of Husserl and Heidegger, beginning with the experience of everyday life, rather than tradition or Scripture or an abstract idea about God, to rethink the transcendence and the possible Revelation of God. Writing as a theologian from the Reformed Tradition I am well aware that from a theological viewpoint the statement of Revelation in theology cannot avoid the basic questions of phenomenology. A phenomenon is that which appears and for Christian theology Christ's Revelation is given as an event that appears within nature and history (Migliore 2004:29-33). For theology God always seeks to make Godself known in the world of human experience. Thus, the statement of Revelation in theology cannot avoid the basic questions of phenomenology, making the work of Marion immensely important for theology today.

The critical question that I want to deal with then, is if the Revelation of God can be related to phenomenology at all? Is it possible for God to appear in nature and history, if God is transcendent to what appears? Since the phenomenology of Husserl has to do with immanence, with what appears in the world, an irresolvable conflict with religion might be imagined. In his translator's introduction of the book, Phenomenology and the "Theological Turn" (2000:115) Bernard Prusak defines the tension between phenomenology and theology as follows: "Since the nineteenth-

1 For an overview of the debate between phenomenology and theology see: Dominique Janicaud in Phenomenology and the "Theological Turn", translation by Bernard G Prusak (New York: Fordham University Press, 2000) that was originally published in French as Le tourment théologique de la phenomenologie francaise by Éditions de l'Éclat (Paris, 1991). For a recent update of the debate see the book edited by Bruce Benson and Norman Wirza, Words of Life: New Theological Turns in French Phenomenology (New York: Fordham University Press, 2010). 
century philosophy of religion starting from Kant and running through Hegel to Nietzsche the choice for philosophy was made clear: either philosophy works within the limits of phenomenological immanence and a transcendent God is wholly consigned to faith (Kant) or philosophy steps beyond these limits to include God within the field of immanence (Hegel), with the result that God is no longer God (Nietzsche)." In his very significant essay, The Saturated Phenomenon (2008:18) Marion himself described the supposed conflict between the philosophy of religion and phenomenology as follows: "It (philosophy of religion) would then find itself confronted with a disastrous alternative: 'it would be a question either of addressing phenomena that are objectively definable but lose their religious specificity or of addressing phenomena that are specifically religious but cannot be described objectively. A phenomenon that is religious in the strict sense would have to render visible what nevertheless could not be objectified. A religious phenomenon in this sense amounts to an impossible phenomenon."

Marion's philosophy concerns precisely the kind of phenomena that appears beyond any objectivity. ${ }^{2}$ The mastery of objects, the longing for objectivity, is one of the characteristics that Marion gives to the nihilism of our time. ${ }^{3}$ Marion places the longing to reduce all phenomena to objectivity, as well as the crisis of nihilism in western culture, before the door of western metaphysics. This brings us to the important discussion in contemporary phenomenology: is phenomenology inherently metaphysical, as Derrida suggests, because it ultimately reduces phenomena to presence, a presence that relies on representation of theoretical consciousness; or does phenomenology offers a way forward beyond metaphysics, as Marion claims (Horner 2005:326)? Phenomenology offers for Marion a post-metaphysical

2 While Marion's comprehension of phenomena and phenomenology is foreshadowed in many of his earlier texts, it is represented most systematically in his phenomenological trilogy: Reduction and Givenness: Investigations of Husserl, Heidegger and Phenomenology (Evanston, EL: North-western University Press, 1998); Being Given: Toward a Phenomenology of Givenness, (Stanford, California: Stanford University Press, 2002a) and In Excess: Studies of Saturated Phenomena (New York: Fordham University Press, 2002b).

3 For Marion our time is marked by nihilism, see The Idol and Distance: Five studies (New York: Fordham University Press, 2001:252), nihilism is "the black sun to which we are delivered", God without Being (Chicago: The University of Chicago Press, 1995:16). 
possibility in its utter emphasis on the self-givenness of phenomena rather than on the reduced consciousness of the subject. Marion wants to open up phenomenology beyond Husserl, who defined a phenomenon as an intentional act of consciousness, as well as Heidegger, who has already, according to Marion, taken a considerable step beyond the constitutive ego of modernity.

Marion is interested in phenomena that we cannot define and see in an objective way, but which still appears to us. He calls these phenomena saturated phenomena. This kind of phenomenon differs so radically from the "poor phenomenon" and "common-law phenomena" of classical phenomenology that it calls for a new phenomenology (Marion 2002a:222). For Marion a saturated phenomenon can be a revelation. In his works Marion carefully stresses the distinction he makes between revelation and Revelation. The fact of Revelation exceeds the scope of all science, including, phenomenology (2002a:367). Revelation with a capital R, as a Christian dogma, belongs to theology to explore, and revelation with a lower case $r$, as an ultimate, yet possible phenomenon, is the concern of phenomenology (I will use this distinction of Marion throughout the article). When Marion writes about the Revelation of Christ he claims that he wants to stay within the limits of phenomenology and that he only wants to outline it as a phenomenological possibility. In Being Given (2002a:234-245) and in In Excess (2002:123-127) he outlines it as the ultimate possibility, the paradox of all paradoxes, a possible saturated phenomenon.

This article wants to explore how Marion's description of Christ Revelation is grounded in the phenomenological concept of "givenness" and the notion of possibility. It will become clear how Marion's understanding of God as an impossible impossibility, is grounded in the phenomenological concept of "givenness", the given and the gift. I will try to show that Marion believes that Husserl's method of phenomenological reduction can be extended to the point where it reveals an unconditioned phenomenon of "pure givenness" (étant donné) and that the fundamental structure of the world turns out to be based on an excess of self-giving. Givenness, for Marion, is only manifested by a process of strict immanence. Therefore the concept of the gift, or rather, the possibility of the gift, occupied a major part of his phenomenological research. 
The phenomena referred to by Marion as saturated, cannot be experienced according to the logic of everyday objects, but only according to the logic of the gift. For Marion the thought of God is also the thought of the gift. Marion confirms this when he tries to resist thinking of God according to being and advocates a thinking of God according to love, expressed in terms of the gift. "God can give himself to be thought without idolatry only starting from himself alone; to give himself to thought as love, hence as gift; to give himself to thought as a thought of the gift" (Marion:1991:49). While Marion has always insisted on a strict distinction between his philosophy and his theology, the structural parallels between the two is obvious. ${ }^{4}$ I would like to show that just as the truth about reality is revealed to phenomenological research as the result of a process designed to reduce all layers of transcendence to immanence, so the theological truth of God, understood as love, becomes manifest only after the complete destruction of his idolatrous representations. The consequence of this is that the radical otherness of God is revealed by careful attention to reality as it is and not by turning away from it and that God's commitment to us is recognized alongside his majestic distance from us (Zachhuber 2011:8). I will argue than in an attempt to differentiate his radical understanding of transcendence and the Revelation of God as an impossible impossibility from the postmodern deconstruction of Derrida, Marion presumes and builds on the negative theology of Dionysius the Areopagite. I will conclude the article by evaluating Marion's post-Kantian reading of Dionysius, showing that it is one-sided and limited, which restricts his value for religious theory and theology.

\section{Metaphysics, givenness, the given and the possibility of the gift}

The crisis of philosophy and theology in late modern societies, for Marion, is entwined with the problem of metaphysics. Marion agrees with Heidegger's interpretation of metaphysics: the difficulty of metaphysical science springs from the problematic character of its unity. How can one and the same

4 Marion admits this in several instances in his work. See Being Given: Towards a Phenomenology of Givenness, 2002a:71-74 and in TL Carlson, 'Translator's Introduction' in The Idol and Distance: Five Studies (Thomas A Carlson (trans.); Jean Luc Marion (ed.), 2001:xi-xxxi. 
science treat at the same time common being (no being in particular) and the being par excellence (a supremely particular being)? For Marion, Heidegger has shown convincingly that in the "inner unity" of metaphysics, which allows it not to fall apart, the single institution of ground is at work. Common being grounds beings, even beings par excellence; and in return, the Being par excellence, in the mode of causality, grounds common being. The unity of metaphysics lies in the intersecting conciliation of beings with the ground, in the mode of causality by Supreme Being.

Nietzsche, who denies that any being par excellence might exercise the function of foundation over common being from some invisible netherworld, of course proclaimed the "end of metaphysics". "No concept of causa sui is admissible, whether as logical, as universal cause, or as moral God" (Marion 2008:53). The original function of the science of the Being par excellence (metaphysica specialis) is thus called into question. It is quite logical that if the figure of "the ground" no longer allows us to legitimate the concept of "metaphysics" in general, it follows that the assimilation of God to the function of the ultimate ground in particular, becomes illegitimate. According to Marion, this ground was always in the history of philosophy interpreted on the basis of effectivity or actuality (Aristotle, Aquinas, Descartes, Leibniz). By "God" metaphysics therefore means the Being par excellence that operates as and through efficiency, such that it can ensure a ground for every common being through metaphysica specialis. For Marion, as for Nietzsche, the "end of metaphysics" provokes the "death" of this "God". Marion's question, after Nietzsche's critique of religion, is: "Does the effectivity of the ground of being really allow us to think the way in which God is God, even in philosophy?" He asks: "Even for the God of philosophers and the scholars, do causa sui, 'sufficient Reason', purus actus, or energia, offer a sufficiently divine name to make God appear?" (Marion 2008:54). Marion identifies the "death of God" with the "end of metaphysics", implying that the overcoming of what Heidegger calls ontotheology, becomes the condition for surpassing the naming of "God" as efficient God.

The question for Marion is whether philosophy itself can escape its metaphysical figure and destiny. Husserl's phenomenology offers for him the way out. There is phenomenology when and only when a statement gives a phenomenon to be seen; what does not appear does not enter into 
consideration (Marion 2008:56). For Husserl, to understand is ultimately to see. To speak is to speak in order to render visible. But how are we to see? Husserl responds explicitly to this question in the opening of Ideas (1913) where he posits what he calls the "principle of principles" which states "that every originarily giving intuition is a source of right for cognition", that everything that offers itself to us in an original "intuition" (in its fleshly actuality) must be received exactly as it gives itself out to be. A phenomenon obtains its phenomenal flesh through intuition (Anschaung or Intuition). "Intuition accomplishes the most fleshly acts of cognition. The flesh of the discourse appears to the flesh of the mind - the phenomenon to intuition" (Marion 2008:56). According to Marion's reading of Husserl, phenomenology calls this encounter givenness (donation): intuition gives the phenomenon, the phenomenon gives itself through intuition (Marion 2008:56). ${ }^{5}$

Marion's later work in phenomenology centres on the problem of givenness. Givenness is one of those concepts, which is very easy to misunderstand. Marion's interest is to diffentiate givenness from other concepts with which it is easily confused. Givenness cannot be reduced to the dichotomy of the object (realism) and the mere appearing of things (phenomenology). They are correlated with one another in the concept of givenness. More importantly for Marion, givenness surpasses the concept of being. Givenness is neither object, nor is it appearance, nor is it even being, but something beyond all of these. Givenness lack of definition results from the fact that it defines all other phenomenological acts" (Marion 2002a:79-84). For Marion, Husserl's project was actually about clarifying different modes or degrees of givenness (2002a:179-234). In terms of Marion's reading of Husserl, givenness cannot be reduced to mere intuition; it does not even always require intuition (2002a:245-247). Marion's understanding of givenness is a radical shift in phenomenology. For Marion, there are four modes of saturated givenness, which he calls the event, the idol, the flesh, the icon

5 Derrida of course challenges this reading of Husserl, as I will show later. For Marion's translation and interpretation of the concept of "gegebenheit" in Husserl's work as "donation", see The Reason of the Gift, (Virginia: University of Virginia Press, 2011) pp 19-34. 
and encompassing all of them, Revelation. ${ }^{6}$ Different kinds of phenomena can be categorized according to the different ways in which they show themselves. Something shows itself insofar as it gives itself. Setting intuition to work as the ultimate instance of givenness has helped Husserl, according to Marion, to go beyond Kant's dualism between the phenomenon and the thing in itself. Since intuition alone gives, the original impression precedes consciousness. It imposes a facticity on consciousness that is not derivate, but original. This reversal of the Kant's apriori principle in favour of the aposteriori principle of givenness means an important reinterpretation concerning ontologia and ground. The givenness of phenomena entails that the appearance of phenomena is operative without having resource to Being (at least necessarily and in the first instance). Phenomenology could free itself absolutely not only from metaphysica generalis (ontologia), but also from the question of Being (Marion 2008:57).

Phenomenology's relief of the metaphysical and ontological concepts entails for Marion first, that actuality is replaced by possibility, in the sense that Heidegger ("higher than actuality stands possibility") reverses Aristotle's fundamental thesis that "the act" ( $\varepsilon \varepsilon \varepsilon \rho \gamma \varepsilon\llcorner\alpha)$ is thus prior to potentiality ( $\delta v v a \mu \varsigma)$ according to genesis and time, as well as according

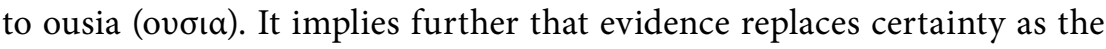
privileged mode of truth and that ousia (ovoเa), as the privileged meaning of Being, is replaced by the given of Being, which straightaway defines for Marion "every being as a being-given" (Marion 2008:58). The being-given designates being such that its Being does not first amount to possessing its own funds (ovola) but to receive itself in Being; to receive Being or, rather, to receive the opportunity to be. That means that one has to extend the status of a beyond of beingness to every being-given.

The second implication of Husserl's so-called "principle of principles" concerns metaphysics in its theological function (Marion 2008:58). The issue is not to argue if the figure of "God" as ultimate ground, "highest Reason" or causa sui is suitable. At issue is simply whether the connection between "God" and all other beings can be understood as ground, or according to an efficient causality. For Marion the "principle of principles" has replaced

6 In his third major work in phenomenology In Excess: Studies of Saturated Phenomena (2002b), Marion deals extensively with what he calls saturated phenomena, see pp 30-127. 
the fact and the effect of being by its most original intuitive givenness, such that the effect of being (grounding, cause) is replaced by being-given (being as given). As being given the phenomenon itself does not have a "why". The relief of the metaphysics specialis of being as grounded effect by phenomenological givenness of being-given, inevitably entails the relief of the metaphysica specialis of the foundation by the phenomenological "source of right" recognized by being-given.

Can phenomenology go further than the "God of metaphysics"? Is the choice a choice between philosophical silence and faith without reason? Does being-given inevitably implies a giver, indeed a being-giver that would bring Marion back to the tradition of metaphysics? For Marion givenness can arise only once causality has been radically surpassed. For Marion being-given does not assume the figure of the giver but the being-given par excellence. "God" is given more than any other being-given. With "God" it is a question of being-abandoned (l'étant-abandonné). ${ }^{7}$ Marion outlines God as the abandoned following the guiding thread of givenness itself. "As the given par excellence, 'God' is given without restriction, without reserve, without restraint. 'God' is given not at all partially, following this or that outline, like a constituted object that nevertheless offers to the intentional gaze only a specific side of its sensible visibility. 'God' is given absolutely, without the least reserve of any outline, with every side open, in the manner of the objects whose dimensions cubist painting caused to explode, in order that all aspects might be juxtaposed, despite the constraints of perspective. 'God' is found given without reserve or restraint" (Marion 2008:62-63).

The evidence displays itself for Marion in the tonality of bedazzlement. This givenness par excellence entails another consequence: the absolute mode of presence that follows from it saturates any horizon, all horizons, with dazzling evidence. Now such a presence without a limit cannot present itself as a limited object. It occupies no space, fixes no attention, and attracts no gaze. In this very "bedazzlement" "God" shines by absence. The absence or unknowability of "God" does not contradict givenness, but on the contrary

7 For a recent insightful reading of Marion's understanding of God as the Abandon, see the article by Joeri Schrijvers: Jean-Luc Marion and the Transcendence par Excellence: Love, in Looking Beyond: Shifting Views of Transcendence in Philosophy, Theology, Art and Politics. Eds. Stoker, W \& Van der Merwe, WL (Amsterdam - New York, 2012) pp $157-172$. 
attests to the excellence of that givenness. "God" becomes invisible not in spite of givenness but by virtue of givenness. Givenness par excellence can thus turn immediately into givenness by abandon. Givenness par excellence lays itself open seeming to disappear (by defect), precisely because it gives itself without reserve (in excess). For Marion it is important not to confuse phenomenology and revealed theology. Phenomenology can identify the saturated phenomenology of the being given par excellence only as a possibility, not as a possibility as opposed to actuality, but above all, as a possibility of givenness itself. The characteristics of the being given imply that it gives itself without prediction, without measure, without analogy, without repetition, in short, it remains unavailable. Between phenomenology and theology, the border passes between revelation as possibility and Revelation as historicity.

The relationship between theology and Marion's understanding of phenomenology is very complex and the debate on the possibility or impossibility of the gift between Jacques Derrida and Marion has become exemplary for thinking the phenomenological possibility of experiencing revelation and the Revelation of God. ${ }^{8}$ The "gift" has become the word used to characterize the possibility or, for Derrida, the impossibility of experiencing God. Robyn Horner (2005:326) argues that the gift polemic of the last decade opens onto two important debates. First, it serves to focus contemporary philosophical discussion about the nature and limits of phenomenology. Is phenomenology inherently metaphysical, as Derrida argues, because it ultimately wants to reduce phenomena to presence that is reliant on representation by theoretical consciousness? Or does phenomenology, following the position developed by Marion, offer a way forward for philosophy beyond metaphysics? The problem of the gift was set out for Derrida in his well known book, Given Time, I. Counterfeit Money (1992) where the conditions of possibility of the gift are simultaneously its conditions of impossibility. For the gift to be identifiable as a gift it must be completely free and present. For Derrida no gift that is ever present is completely free, and if it is not present then we cannot know it as a gift. The gift structurally embodies what Derrida calls "the impossible". For Derrida

8 See the major contribution of Robyn Horner to the debate by interpreting Marion and Derrida's phenomenological work in terms of the gift; Rethinking God as gift: Marion, Derrida and the Limits of Phenomenology (New York: Fordham University Press, 2001). 
there cannot be a phenomenology of the gift, because phenomenology attempts to reduce phenomena to presence, a present gift, losing its characteristic of freedom, which would make it no longer a gift. But Derrida does not give up on the gift. While the gift may not be known, it might still be thought as the impossible, and risked according to desire and decision (Horner 2005: 327).

Horner points out that the difficulty with Derrida's position is that the risk of the gift is the risk of deception. I don't know for sure, but instead only have a kind of faith in the gift. Marion differs from Derrida. Phenomenology can deliver the gift, because the phenomenological reduction to givenness operates to remove the gift from the schema of causality. For Marion the problem of the gift, as Derrida has articulated it, is overcome through the suspension of any one or two of the parts that constitutes a gift: the giver, the gift object, or the recipient. The gift is removed from the cycle of metaphysical causality either because it loses its giver through the reduction of its transcendence, or because it loses its object-ness and is no-thing as such, or because it ultimately has no recipient that can be determinated by the giver. While Derrida requires these three conditions to operate simultaneously, Marion stresses that only one or two of the three is effective at any given moment (Marion 2002a:71-113). Marion's problem, from Derrida's perspective, is that for the gift to be a gift any one or two of the elements of giving, the gift, or receiving, can always be identified, and therefore is always and already undone according to Derrida's conditions.

The second debate onto which the gift polemic opens is a theological debate (Horner 2005:327). Theology makes much of the category of the gift when it comes to God. The grace of God is nothing other than God's self-giving in a relationship with human beings. This leads to a peculiar problem. If God is always already giving Godself as the offer of that relationship, and on the other hand, beyond all capacity of human understanding, the problem is if such a relationship is a possibility, because a loving relationship is characterized by freedom and by presence, the relationship between parties can at least be recognized. Yet God's presence would destroy the very possibility of the relationship being free and present for it would override the limitations of human knowledge and would therefore eliminate the possibility of choice to enter into the relationship. Once 
again: the conditions of possibility for relationship with God are also the conditions of impossibility (Horner 2005:328).

Marion insists that the revelatory self-giving of God is a theme that can only be worked out on the basis of Revelation (capital R) and he points out both that capital Revelation cannot be phenomenologically deduced and that theological questions lie properly beyond the scope of phenomenology. Nevertheless, Marion still considers the possibility of Revelation as a saturated phenomenon that exceeds the capacity of the recipient to constitute them in any ultimate way: "According to this hypothesis, the impossibility of attaining knowledge of an object, does not come from a deficiency in the given intuition, but from its excess, which neither concept nor signification nor intention can foresee, organize, or contain" (Marion 2002:159). Such phenomena cannot be contextualized according to the normal Kantian categories and appear only as dazzling, overwhelming or excessive. This coincides with what is given in mystical theology where God remains incomprehensible, but not imperceptible - without adequate concept, but not without giving intuition.

Marion's argument that phenomenology can do no more than sketch the conditions for the possibility of revelation with a small rather than the actuality of Revelation with a capital $\mathrm{R}$ is not unproblematic and raises at least two huge problems in terms of phenomenology. Derrida queries his overall commitment to theology in the working out of his phenomenology and has reservations about the possibility of that commitment. Derrida's problem is what he calls the "deep ambition" in Marion's thought, has the consequence that everything becomes a gift. "For you everything that is given in the phenomenological sense, gegeben, donné Gegenbenheit, everything that is given to us in perception, is finally a gift to a finite creature, and it is finally a gift of God" (Derrida in Horner 2005:329). The second concern in terms of phenomenology comes from Dominique Janicaud who maintains that Marion's frequent use of a capital letter when he speaks of $r /$ Revelation seems to suggest that he is not only interested in the possibility of revelatory phenomena, but also in their actuality and that they become theological truth claims (Horner 2005:329). The question is: How does Marion answer to the critique of Derrida and Janicaud? For Marion the difference with Derrida, Caputo and others lies in the different ways that they interpret the concept of God as "posse". 


\section{Revelation of God as an impossible impossibility}

Both Derrida and Marion want to think the divine in terms of posse rather than esse (Kearney 2005:298). For Derrida there is interplay between the possibility and impossibility when he thinks about friendship, decision, responsibility, interpretation, invention, forgiveness etc. All of these phenomena have, for Derrida, the structure of an aporia. Like the gift, the conditions of the possibility are at the same time the conditions of their impossibility. For these events to be possible they must also be impossible. They happen not just because of the acting out of some inherent potential, but also because something impossible, something unanticipated, comes to pass. It is precisely the impossibility of formerly predictable possibilities which makes new ones announce themselves beyond this very impossibility. The impossible reminds us that beyond our powers the impossible is still possible, for Derrida argues that im-possibility is not the opposite of possibility, but rather the mark of renewal and arrival as event (Kearney 2005:300).

While Derrida's reflection on the question of God and faith remains open for new interpretations, he is not particularly interested to pursue these issues in a theological or theistic manner. He will declare the impossible-possible paradox of pardon/gift/justice/hospitality as a general 'messianic' structure of all experience; but he did not see it as his business to pronounce on the authentically theistic or atheistic important of any given messianism" (Kearney 2005:304). For Derrida, Messianism refers to a vigilant openness to the incoming events of all our experiences, be it sacred or profane; good or evil, loving or violent. Derrida's concern is with the everyday incoming of events and not the truth of some divine advent. That is why Derrida refrains from responding one way or another to any particular claim about God. Derrida sees in the play of the possible-impossible a structure that resonates with human experience in general, while Marion is interested in a specifically religious experience of God. This is for Marion not only a question of rhetoric, but also of "givenness", or a difference that is not only in names and signs but a difference beyond Derrida's difference. For Marion, as for Derrida, no language can articulate or describe the "experience of God" without turning the very experience into an idea or concept governed by the logic of language. Is it possible then that the logos (of philosophy) could ever think God outside language? Is it possible that 
the religious could be thought at all? Marion wants to attempt precisely this: to say the unsayable, to think the unthinkable, to make possible what remains impossible.

How does Marion imagine the possibility of God? In terms of experience it is obviously clear that we don't have an intuition of God in experience or a concept at our disposal. Intuition is about what we can experience within the parameters of space and time. The possibility of God postulates that all conditions of intuition must be transgressed; because intuition implies space and time there can never be any intuition of God because there is an even more radical requirement, that there must not be any intuition. But "God" is a double impossibility because we cannot legitimately assign any concept to God, since every concept, by implying delimitation and comprehension, would contradict God's sole definition, namely that God transcends all delimitation and therefore all definitions. None of our concepts that we use to designate God have the power, by definition to reach God. As far as the traditional conflict between phenomenology and religion goes, Marion concludes that regarding God, we actually have a triple impossibility. The Revelation of God is an impossibility with regard to intuition, an impossibility with regard to a concept and therefore an impossibility to experience (Marion 2007:24).

While it is impossible to have an intuition, concept or experience of God there is something imprescriptible that philosophy can't deny and that remains forever a question, according to Marion. The fact that the question of God survives the phenomenological impossibility of God is a paradox, of which philosophy must give a rational account off. "The question of God survives the impossibility of God. Reason itself requires therefore that we give a rational account of this paradox. We must either explain it, or give up and give in to it" (Marion 2007:24). The problem is to explain how the impossible endures a possibility, to conceive how the thought of the impossible remains. The question concerns the limits of our rationality. How can we conceptualize what escapes us? This paradox can only be dealt with by recognizing that "God and God alone, lets himself be defined by impossibility as such" (Marion 2007:25). God begins where the impossible for us ends. For Marion it is exactly this impossibility that makes God "possible": "God begins where the possible for us ends, where what human reason comprehends as possible for it comes to a halt, at the precise limit 
where our thought can no longer advance, or see, or speak - where the inaccessible domain of the impossible bursts open" (Marion 2007:25).

What is impossible for us is precisely God's characteristic possibility. For God nothing is impossible. Marion wants to think an impossibility that transcends all impossibility. He calls this radical impossibility of God that transcends all impossibility, an impossible impossibility. What are the implications of God manifesting Godself in such a way that nothing is impossible? The first implication for Marion is the conversion of the impossible for us into the possible for God. The impossible delineates only the region of finitude, which belongs to us. The experience of the impossible is a threshold that we (confined to finitude) can only cross when we consider what remains incomprehensible for us, namely by conceiving that what is irreducibly impossible for us can or could become possible in its own right if we were to pass over to God's viewpoint. We must conceptualise what remains incomprehensible, namely that God starts where the impossible translate into the possible. God defines himself as that to which there is no possibility of impossibility.

For Marion this leads to a second consequence: if no impossibility operates or has sway over God, then nothing can make God himself impossible. “...it is impossible for God to be impossible" (Marion 2007:28). Marion turns the argument that the impossibility of God is proved on the grounds of intuition, meaning, and therefore phenomenologically, against itself, because the impossibility of experiencing God obviously concerns us only as humans, who alone are capable of experiencing the impossible. It has no meaning for God. The impossibility of God turns out to be possible only for us and not for God. Marion insists that the impossibility of impossibility for God remains inaccessible for us (but not for God). It teaches us nothing about God.

Thirdly, it follows that the so-called "ontological argument" in metaphysics, according to Kant's formulation that consists in deducing God's existence from the concept of God's essence and other pure concepts, must be radically transformed. The problem for Marion lies in the assumption that a concept can define the divine essence, resulting in forging an idol of "God." Renouncing all concepts of God and sticking to his incomprehensibility can only overcome this aporia. Incomprehensibility is for Marion in the tradition 
of Dionysius the Areopagite, the distinct hallmark of God's difference with regard to humanity. For Marion to substitute a comprehensible concept for the incomprehensible concept of the impossible, no longer proves God's existence, but the impossibility of his impossibility, and therefore his possibility. "God turns out to be the one whose possibility remains forever possible, precisely because it turn out that nothing remains impossible for him, especially not himself. The necessity of God's possibility flows from the impossibility of his impossibility" (Marion 2007:29).

God's impossibility must be distinguished clearly from what Marion calls the impossibility of metaphysical theology where God is defined as omnipotent, which emphasizes that God can do anything God pleases as long as it does not violate the principle of non-contradiction. Marion wants to displace the idea that God is an abstract and arbitrary power that can do anything with the more radical idea of love and fidelity. Marion uses the Annunciation in Scripture, where the angel Gabriel told Maria that she would give birth to the child Jesus and then assures her that with God nothing is impossible to illustrate this point on more than one occasion. The impossibility of God here must not be contributed to God's omnipotence, but a manifestation of God's fidelity. "Let this be done according to God's word, for God will be true to his word. We as humans find it hard and sometimes impossible to be true to our words, but not God. God will always keep God's promises. "God is not someone powerful enough to do anything God wants, but someone who wants only by loving." (Marion 2007:35).

\section{What does Marion give theology?}

The question is what does Marion give theology when he describes God as an impossible impossibility that is unknowable and incomprehensible? Is there really a difference between Derrida's undetermined "God" of deconstruction which is impossible to be present or to be experienced and Marion's God that is given absolutely, but transcends all concepts and ideas about God? Someone like Richard Kearney, in his book, The God Who May Be, calls this God of Marion, "too transcendent" (Kearney 2001:32). Caputo admits that Marion's post-metaphysical discourse challenges the ontological foundation of Western philosophy and theology in a radical way, but for Caputo this God is too radical. This is where faith runs off "the 
road of language and history" (Caputo in Taylor 2006:5). Caputo hesitates in front of this God without being, and reinstates a Derridean trace into the conversation. This means that Marion's denominating of God does not necessary free God from the work of difference. God is not only subject to "difference", but also to "deferral". Caputo formulated the tension between Marion and Derrida's understanding of the possibility and impossibility of the naming of God as follows:

We have contended that Marion and Derrida are agreed in regarding the "intention" or the "concept" as an "arrow" which is aimed at the heart of God from which God must be 'shielded" or kept "safe". For Marion, who is thinking in terms of Christian Neo-Platonism of Pseudo-Dionysius, this is because the arrow of intentionality is too weak and narrow to penetrate or comprehend the infinite givenness of God; it would compromise the infinite incomprehensibility of God who has utterly saturated the intention "God" in a plenitude of givenness. But for Derrida who is thinking in Jewish and messianic terms, not those of Christian Neo-Platonism, the arrow takes aim at God and never reaches because the name of God is the name of what we love and desire, of that for which we pray and weep, something "tout autre" which is not" present", not only in narrow sense of conceptual presentation advanced by Marion, but also not given. For Marion, the signifier "God" is flooded with givenness; for Derrida it is dry and desert aspiration for I know not what (Caputo 1999:199).

We can say that in terms of Caputo's reading, Derrida's God is not "there to us", but in the case of Marion, God is "there" in an absolute sense but forever unnameable. Is a more constructive theological reading of Marion possible? I want to argue with the church historian from Cambridge, Johannes Zachhuber, that Marion has developed, in anticipation of the post-modern critique of metaphysics and religion, a very particular reading of the negative theologian Dionysius. This reading has a lot of potential for theology today, but it also limits the worth of Marion's work for theology. Zachhuber (1991:141) argues that it is in response to the theological difficulty posed by the Biblical idea of God's revelation-in-concealment that Marion interprets Dionysius's so-called negative theology. In Marion's view, the essence of Dionysius' negative-, or as Marion prefers to call it, mystical theology is a linguistic model that presupposes the dispossession of 
meaning. So the critique of metaphysics in Nietzsche and Heidegger serves a theological purpose of making room for the establishment of a radically different discourse based on the principle of love. The Biblical word that God is love (1 John 4:16) means that God is not a being, nor is God 'being'. For Marion the modern and postmodern critique of metaphysical theism is correct and appropriate, but it is ultimately only an extension of the theological critique of idols and does not deny the legitimacy of theology.

Negative theology for Marion is thus a critical theological method intended to escape idolatry. Idolatry includes naïve visual representations of God, but even more dangerously attributes and concepts applied to God by philosophical or theological language. To avoid such idolatry, one must deny objects and attributes as imperfections. Even the loftiest attributes must be denied, such as the One, Unity, Divinity or Goodness. But even this is not sufficient; because it can appear that negation itself reveals the being of God. In Idol and Distance (2001:147) Marion states that if this were the case, negative theology itself would be idolatrous. Marion reads Dionysius in such a way that negation itself must be denied and God postulated as being beyond affirmation and negation. As a postmodern philosopher, Marion makes it clear that if negative theology is understood in this way, all theology becomes impossible. If negative theology is the negation of all theology, its truth is atheism (Marion 2001:147). It also takes the believer into the abyss of a godforsaken world, to the point enunciated in the word of Christ on the cross: 'My God, why hast thou forsaken me?' (Zachhuber 2011:11).

For Marion, Dionysius also takes us beyond this point. In his debate with Derrida in Villanova 1997, he notes that Dionysius is still willing to use one word for God until the end, and this is, 'cause' (aitia). In this notion the unity of distance and intimacy is given that permits us to move beyond the impasse of pure apophaticism. At the point of utter negation it becomes possible to relate to God in a new way (Zachhuber 2011:11). Marion sees in Dionysius a third way beyond affirmation and negation that he connects with Dionysius' mentioning of cause right at the end of The Mystical Theology. Cause, of course, does not mean cause sui of metaphysics, but indicates that God is beyond affirmation and negation insofar as he is love, pure giving, or as suggested in the Divine Name by Dionysius, Goodness. Goodness and cause is, according to Marion interchangeable in Dionysius's thought. 
There are problems with Marion's mystical theology. Marion argues that the "hyper" that someone as Dionysius invoked to indicate the ineffability of God, transgresses the order of essence or knowledge in favour of a praise that precedes every essence. As Kearney notes: the "hyper" of negative theology means that God is radically devoid of being and safely beyond the reaches of onto-theology understood as metaphysics of presence (Kearney 2001:32). In the end, Marion distils negative theology into a theology of radical absence. God is a God of hyper-excess that cannot be seen, known or understood. God surpasses all prediction and narration.

In his oversensitivity for the postmodern critique of idolatry, Marion diminishes not only scholars like Dionysius, but the whole tradition of analogical thinking. The relation of God to creation is reduced to a God of radical absence. Marion tends to read Thomas Aquinas's notion of analogy simply in logical terms, however, the existential implications of thought must be carried out as well. We as creatures are analogously related to God existentially. God transcends us, but is also immanent. This is articulated in the concept of analogia entis (Betz 2005:368). Like the artist who leaves a trace in his work efficiently executed, so too does God the Creator leave a trace in us as His creatures. In the tradition of analogia entis God and creatures' real being are not identical in any way. Marion's charge against theology is that God is idolized by conceptualizing God as causa sui, but it would not be difficult to show that Marion's reading of causality is very limited in that he does not examine the full implications of the relation between cause and effect. If we are to think God, we must somehow be related to God, be it in thinking, love or being. I agree with Patrick Masterson that the phenomenological approach to theology and philosophy of religion is incomplete without the metaphysical. In his thoughtful book, Approaching God: Between Phenomenology and Theology (2013), Masterson discusses two approaches to the philosophical understanding of God: the phenomenological, exemplified by Jean-Luc Marion, and the metaphysical, represented by Thomas Aquinas. In the end, Masterson sees value in both of these approaches and considers them complementary to each other. I imagine this to be a more fruitful way forward for the debate between phenomenology, metaphysics, philosophy of religion and theology. 


\section{Bibliography}

Benson, EL \& Wirzba, N 2010 (eds.). Word of Life: "New Theological Turns in French Philosophy". New York: Fordham University Press.

Betz, BR 2005. Beyond the Sublime: The aesthetics of the analogy of being (Part 1). In: Modern Theology (21:3). pp. 367-411.

Caputo, JD 1999. Apostels of the Impossible: On God and The Gift in Derrida and Marion. In: God, The Gift, and Postmodernism. Caputo

DJ \& Scalon, MJ (eds.). Indianapolis: Indiana University Press. pp 185-199.

Derrida, J 1992. Given Time: I Counterfreit Money. Chicago and London: The University of Chicago Press.

Horner, R 2001. Rethinking God as Gift. Marion, Derrida and the Limits of Phenomenology. New York: Fordham University Press.

Horner, R 2005. Aporia or Excess? Two Strategies for Thinking Revelation. In: Derrida and Religion: Other Testaments. Sherwood, Y \& Hart, K (eds.). New York: Routledge. p 325-336.

Janicaud, D 1991. Phenomenology and the "Theological Turn". New York: Fordham University Press.

Kearney, R 2001. The God Who May Be: A Hermeneutics of Religion. Bloomington and Indianapolis: Indiana University Press.

Kearney, R 2005. Deconstruction, God and the Possible. In: Derrida and Religion: Other Testaments. Sherwood, Y \& Hart, K (eds.). New York: Routledge. pp 297-297.

Marion, JL 1991. God Without Being. Chicago: University of Chicago Press.

Marion, JL 1998. Reduction and Givenness: Investigations of Husserl, Heidegger and Phenomenology, Evanston, EL: Northwestern University Press.

Marion, JL 2002(a). Being Given: Toward a Phenomenology of Givenness. Stanford, California: Stanford University Press. 
Marion, JL 2002(b). In Excess: Studies of Saturated Phenomena, New York: Fordham University Press.

Marion, JL 2007. The impossible for Man-God. In: Caputo, JD \& Scanlon, MJ (eds.). Transcendence and Beyond: A Postmodern Inquiry.

Bloomington: Indiana University Press.

Marion, JL 2008. The Visible and the Revealed. New York: Fordham University Press.

Marion, JL 2011. The Reason of the Gift. Virginia: University of Virginia Press.

Masterson, P 2013. Approaching God: Between Phenomenology and Theology. New York: Bloomsbury.

Migliore, DL 2004. Faith Seeking Understanding: An Introduction to Christian Theology. Michigan \& Cambridge: William B Eerdmans Publishing Company.

Prusak, BG 2000. “The Phenomenology of religion: new possibilities for philosophy and religion." In Phenomenology and the "Theological Turn": The French Debate. New York: Fordham University Press. pp 107-120.

Schrijvers, J 2012. "Jean Luc Marion and the Transcendence par Exellence: Love." In: Looking Beyond? Shifting Views of Transcendence in Philosophy, Theology, Arts and Poitics. Stoker, W \& Van der Merwe, WL (eds.).

Taylor, ET 2000. “A Converation With Jean-Luc Marion.” Journal for Cultural and Religious Theory (vol. 7 no. 2). pp 1-6. 